Vol. 5 (1996): 509-514.

\title{
In vitro production of cattle blastocysts in chemically defined medium with or without insulin supplementation
}

\author{
Kristiina Bredbacka and Peter Bredbacka \\ Agricultural Research Centre of Finland, Institute of Animal Production, FIN-31600, Jokioinen, Finland, \\ e-mail: kristiina.bredbacka@mtt.fi
}

\begin{abstract}
In this study we evaluated the use of a chemically defined medium in the production of blastocysts from bovine oocytes fertilized in vitro. As culture medium we used CR1-PVP, a modification of CR laa medium with bovine serum albumin replaced by polyvinylpyrrolidone. After $168 \mathrm{~h}$ of culture (192 h after insemination) $8.7 \%, 10.5$ and $12.8 \%$ of the cleaved embryos developed to the blastocyst stage in the presence of 0,2 or $200 \mathrm{nM}$ insulin, respectively. The supplementation of $200 \mathrm{nM}$ insulin tended to increase cell numbers in morulae and blastocysts $(\mathrm{P}=0.10)$. It is concluded that CR1-PVP can be used as a chemically defined medium in the production of blastocysts from bovine 1-cell embryos. However, further modifications are needed, and the insulin concentrations used may be below the optimum for blastocyst production.
\end{abstract}

Key words: bovine, embryo culture, polyvinylpyrrolidone, cell number, Hoechst 33258

\section{Introduction}

Currently the in vitro production (IVP) of bovine embryos is most efficiently carried out using serum- supplemented culture media and with co-culture with somatic cells (for review, see Brackett and Zuelke 1993). As serum consists of numerous unknown ingredients these media are termed undefined media. Improving such a medium by analysing the supplementation of various ingredients is complicated as the medium may already include these ingredients. Furthermore, the components tested may interact with ingredients present in the serum, and the effects may vary according to the batch of serum used. An alternative approach for studying the media component requirements of embryos is to use chemically defined media. Although still less supportive for growth than the best undefined media, such defined media have been shown to support embryonic development to the blastocyst stage (Pinyopummintr and Bavister 1991, Takagi et al. 1991, Seidel et al. 1991a, 1991b, Kim et al. 1993, Keskintepe et al. 1995)

In recent years attention has been paid to the effect of supplementing media with growth factors (Herrler et al. 1992, Flood et al. 1993, Heyner et al. 1993). Transcripts for receptors for insulin and the growth factors IGF-I, IGF-II and 


\section{AGRICULTURAL AND FOOD SCIENCE IN FINLAND}

\section{Bredbacka, K. \& Bredbacka, P. Bovine blastocyst production in defined medium}

PDGF- $\alpha$ are detectable throughout bovine preimplantation development (Watson et al. 1992), implying that the use of these growth factors in culture media could have beneficial effects on embryonic development. The effects of insulin on mouse embryo development have been characterized reasonably well (Rosenblum et al. 1986, Harvey and Kaye 1988, 1991, Rao et al. 1990), but relatively little is known about its effect on bovine embryos.

The objective of our study was to evaluate the use of a chemically defined bovine embryo culture medium with polyvinylpyrrolidone (PVP) as a macromolecular substitute for serum or serum albumin. Furthermore, using this medium, we examined the effect of insulin supplementation on bovine embryo development to the morula and blastocyst stage.

\section{Material and methods}

\section{In vitro maturation}

Cattle ovaries were obtained from an abattoir and transported to the laboratory at room temperature in $0.9 \%(\mathrm{w} / \mathrm{v}) \mathrm{NaCl}$ supplemented with 100 $\mathrm{IU} / \mathrm{ml}$ penicillin and $100 \mu \mathrm{g} / \mathrm{ml}$ streptomycin. The oocytes were aspirated from follicles with a diameter of 3-8 mm. Only oocytes surrounded by cumulus cells were selected for maturation. Oocyte-cumulus complexes were washed twice in TALP-HEPES (Parrish et al. 1988). Hepes was obtained from Sigma (St. Louis, MO, USA). The maturation medium was TCM199 (Sigma, Cat No. M 0148) supplemented with $0.25 \mathrm{mM}$ sodium pyruvate, $2 \mathrm{mM}$ L-glutamine, $100 \mathrm{IU} / \mathrm{ml}$ penicillin, $100 \mu \mathrm{g} / \mathrm{ml}$ streptomycin, $2 \mu \mathrm{g} / \mathrm{ml} \mathrm{FSH}$ (USDA-oFSH-18; USDA, Beltsville, MD, USA), $10 \mu \mathrm{g} / \mathrm{ml}$ LH (USDA-bLH-B-6; USDA, Beltsville, MD, USA), $1 \mu \mathrm{g} / \mathrm{ml}$ oestradiol (Sig$\mathrm{ma}), 5 \%(\mathrm{v} / \mathrm{v})$ foetal calf serum and $5 \%(\mathrm{v} / \mathrm{v})$ oestrous cow serum. In each $500-\mu l$ drop of medium, 40-50 oocyte-cumulus complexes were matured for $24 \mathrm{~h}$ in $5 \% \mathrm{CO}_{2}$ in air at $39^{\circ} \mathrm{C}$.

\section{In vitro fertilization}

After maturation, oocyte-cumulus complexes were washed in TALP-HEPES and transfered to $100-\mu l$ fertilization drops covered with embryotested mineral oil (Sigma). The fertilization medium was fert-TALP (Parrish et al. 1988) supplemented with $2 \mu \mathrm{g} / \mathrm{ml}$ heparin, $2 \mu \mathrm{M}$ penicillamine, $10 \mu \mathrm{M}$ hypotaurine and $1 \mu \mathrm{M}$ epinephrine (Sigma). Frozen-thawed spermatozoa were washed twice in sperm-TALP (Parrish et al. 1988 ), and $1.5 \times 10^{6} / \mathrm{ml}$ spermatozoa was added to each fertilization drop. After 24-h fertilization at $39^{\circ} \mathrm{C}$ in $5 \% \mathrm{CO}_{2}$ in air, the cumulus cells were removed by vortexing.

\section{In vitro culture}

The oocytes were washed in CR1+PVP, a modification of the CR laa medium (Rosenkrans and First 1991) including $4 \mathrm{mg} / \mathrm{ml}$ polyvinylpyrrolidone (PVP; Sigma, Cat No. P 2307) instead of BSA. The oocytes were randomly selected and placed into one of three culture media, CR 1+PVP, CR1+PVP supplemented with $2 \mathrm{nM}$ insulin (Sigma, Cat No. I 1882) and CR1+PVP supplemented with $200 \mathrm{nM}$ insulin. About 20 to 40 embryos were cultured in each $50-\mu \mathrm{l}$ drop of medium covered with mineral oil at $39^{\circ} \mathrm{C}$ in a humidified atmosphere of $5 \% \mathrm{CO}_{2}$ in air. After $96 \mathrm{~h}$ of culture, glucose (final concentration 5.56 $\mathrm{mM}$ ) and fresh CR 1 aa medium were added to each culture drop (final volume $100 \mu \mathrm{l}$ ). The embryos were evaluated for development on Day 8 (fertilization $=$ Day 0 ) using the criteria of Lindner and Wright (1983). However, embryos lower than Grade 2 were not classified as morulae or blastocysts. The cell numbers of the embryos were counted after staining with $3 \mu \mathrm{g} / \mathrm{ml}$ Hoechst stain 33258 in $15 \%$ of ethanol in PBS for 24 to $48 \mathrm{~h}$ at $+4^{\circ} \mathrm{C}$. The embryos were then washed and placed in a 1- $\mu$ l drop of PBS into a 10 to $15 \mu \mathrm{l}$ drop of a mixture of glycerol and water $(5: 1)$ on a glass slide. The embryo was then overlaid with a coverslip and examined under a Leitz Dialux 20 microscope using the Leitz A 
Vol. 5 (1996): 509-514.

Table 1. Development of bovine embryos cultured for 7 days in CR1+PVP medium with different insulin concentrations.

\begin{tabular}{cccccc}
\hline Insulin (nM) & Oocytes & \% Cleaved & $\begin{array}{c}\text { \% Morulae } \\
\text { +blastocysts }\end{array}$ & \% Blastocysts ${ }^{1}$ & $\begin{array}{c}\text { Cells }^{2} \\
\text { (least square means) }\end{array}$ \\
\hline 0 & 168 & 75.6 & 11.0 & 8.7 & 56.9 \\
2 & 172 & 72.1 & 16.9 & 10.5 & 58.3 \\
200 & 167 & 79.6 & 14.3 & 12.8 & 71.2 \\
\hline
\end{tabular}

\footnotetext{
' Proportion of cleaved oocytes.

${ }^{2}$ Hoechst 33258-stained nuclei in morulae and blastocysts.

There were no significant differences $(\mathrm{P}>0.05)$ between treatments in cleavage rate, proportion of morulae and blastocysts, proportion of blastocysts ( $\chi_{2}$-test) or in number of nuclei (ANOVA).
}

filter block. The experiment was repeated 5 times.

\section{Statistical analysis}

Proportions (cleaved embryos of inseminated oocytes, Grade 1 and Grade 2 compacted morulae and blastocysts of cleaved embryos) were compared with the $\chi^{2}$ test. The cell numbers of embryos of transferable quality (Grade 1 and Grade 2 morulae and blastocysts) were compared using the GLM program of SAS (SAS Institute, Cary, NC, USA). The effect of the replicates was included in the model.

\section{Results}

The results are summarized in Table 1. Of the cleaved embryos, $8.7 \%$ developed to the blastocyst stage in the absence of proteins. Insulin supplementation did not significantly increase cleavage rate or development to the morula and blastocyst stage, but supplementation with $200 \mathrm{nM}$ insulin tended to increase cell proliferation in morulae and blastocysts $(\mathrm{P}=0.10)$. The highest cleavage rate, the highest proportion of blastocysts and the highest number of nuclei in morulae and blastocysts were achieved with the highest concentration of insulin used.

\section{Discussion}

By extending the the previous observations of Pinyopummintr and Bavister (1991) and Takagi et al. (1991) we demonstrate in this study the possibility of culturing bovine zygotes to the blastocyst stage in a protein-free, chemically defined medium. The medium we used contained PVP as a macromolecular compound. Although we did not here compare it with other macromolecular ingredients, we have previously shown that PVP supports early cleavage better than does foetal calf serum (Bredbacka and Bredbacka 1995). PVP is of non-biological origin and we use it as a surfactant to facilitate subsequent embryo handlings.

Takagi et al. (1991) produced 4\% blastocysts per cleaved embryo using protein-free TCM-199 as the culture medium. Pinyopummintr and Bavister (1991) reported a success rate of 10$15 \%$ blastocysts/cleaved oocyte in their proteinfree culture system (either TCM199 or HECM). Our success rate of $8.7 \%$ blastocysts in $\mathrm{CR} 1+\mathrm{PVP}$ medium is similar to the rates reported in the above two studies, although our culture time was one day shorter than that used by Pinyopummintr and Bavister. Our cleavage rate $(75.6 \%)$ was, however, significantly lower than theirs (about $95 \%$ ). This difference may be due to differences in the in vitro fertilization protocol rather than in the compositions of the culture media. 


\section{AGRICULTURAL AND FOOD SCIENCE IN FINLAND}

\section{Bredbacka, K. \& Bredbacka, P. Bovine blastocyst production in defined medium}

Recent studies stress the importance of amino acids in the production of bovine blastocysts in protein-free media. Using a modified TLP medium, Kim et al. (1993) produced $0-1 \%$ blastocysts without amino acids as against $9-13 \%$ in the presence of amino acids. Keskintepe et al. (1995) produced $10.9-18.4 \%$ blastocysts in protein-free SOF medium with an increase to $28.4-$ $42.3 \%$ with the addition of non-essential amino acids. The medium we used also contained amino acids, but probable not at optimal concentrations, as recent studies indicate that bovine embryo development is supported by increased concentrations of glycine and alanine (Moore and Bondioli 1993).

Using TCM-199 as control medium, Jiang et al. (1990) found no beneficial effect of insulin supplementation $(10 \mu \mathrm{g} / \mathrm{ml}$ or $50 \mu \mathrm{g} / \mathrm{ml})$ on bovine morula and blastocyst development. However, Seidel et al. (1991b) reported a beneficial effect of $5 \mathrm{IU}$ insulin on blastocyst formation in chemically defined medium (CDM). The insulin supplemenation in our study tended to increase the proportions of morulae and blastocysts at the highest concentration used ( $200 \mathrm{nM})$. Similarly, the average cell number in morulae and blastocysts increased with the increase in the insulin concentration. Although neither of these trends was statistically significant, taken together, they may imply a supportive role of insulin. We decided to test very different concentrations because of the wide range of concentrations used in studies on biological effects reported in the literature. The lower concentration $(2 \mathrm{nM})$ falls well in the range of $1.7 \mathrm{pM}-170 \mathrm{nM}$, which has been found to be stimulatory for protein synthe- sis in mouse embryos (Harvey and Kaye 1988). On the other hand, Seidel et al. (1991b) used $5 \mathrm{IU}$ of insulin with beneficial effects on the bovine. We used only about 0.003 units at the end of culture even with the higher concentration of insulin. It is possible that cattle embryos require considerably higher insulin concentrations than mouse embryos in an in vitro situation. Lower concentrations may act via insulin receptors, whereas high concentrations of insulin are required for binding to insulin-like growth factor I (IGF-I) receptors. Transcripts for both receptors are present throughout bovine preimplantation development (Watson et al. 1992).

Whether insulin shows a beneficial effect or not may depend not only on the concentration of insulin, but also on the culture medium components used. Zhang and Armstrong (1990), for instance, observed that insulin was beneficial for the development of 8-cell rat embryos only in the presence of amino acids. The optimal concentration of insulin may therefore differ from one medium to another.

In conclusion, our study demonstrates the feasibility of producing bovine blastocysts from 1-cell stage embryos in a protein-free CR1aa medium supplemented with PVP. Addition of $200 \mathrm{nM}$ insulin tended to facilitate blastocyst formation. Higher insulin concentrations than those used here may be required for an acceptable quality and rate of morulae and blastocysts.

Acknowledgements. The authors are grateful to T.-M. Nieminen and J. Peippo for technical support. FSH and LH were kindly provided by D.J. Bolt (USDA Animal Hormone Program, Beltsville, MD, USA).

\section{References}

Brackett, B.G. \& Zuelke, K.A. 1993. Analysis of factors involved in the in vitro production of bovine embryos. Theriogenology 39: 43-64.

Bredbacka, K. \& Bredbacka, P. 1995. Effect of polyvinylpyrrolidone, serum albumin and fetal calf serum on early cleavage of bovine embryos. Theriogenology 43: 174. (Abstract).
Flood, M.R., Gage, T.L. \& Bunch, T.D. 1993. Effect of various growth-promoting factors on preimplantation bovine embryo development in vitro. Theriogenology 39: 823-833.

Harvey, M.B. \& Kaye, P.L. 1988. Insulin stimulates protein synthesis in compacted mouse embryos. Endocrinology 122: 1182-1184. 


\section{AGRICULTURAL AND FOOD SCIENCE IN FINLAND}

Vol. 5 (1996): 509-514.

- \& Kaye, P.L. 1991. Mouse blastocysts respond metabolically to short-term stimulation by insulin and IGF-1 through the insulin receptor. Molecular Reproduction and Development 29: 253-258.

Herrler, A., Lucas-Hahn, A. \& Niemann, H. 1992. Effects of insulin-like growth factor-I on in-vitro production of bovine embryos. Theriogenology 37: 1213-1224.

Heyner, S., Shah, N., Smith, R.M., Watson, A.J. \& Schultz, G.A. 1993. The role of growth factors in embryo production. Theriogenology 39: 151-161.

Jiang, H.S., Wang, W.L., Lu, K.H. \& Gordon, I. 1990. Effects of PMSG, insulin, osmolarity and oestrus cow serum on development of IVF early bovine embryos cultured on granulosa cell monolayers. Theriogenology 33: 258. (Abstract).

Keskintepe, L., Burney, C.A. \& Brackett B.G. 1995. Production of viable blastocysts in defined in vitro conditions. Biology of Reproduction 52: 1410-1417.

Kim, J.-H., Niwa, K., Lim, J.-K. \& Okuda, K. 1993. Effects of phosphate, energy substrate, and amino acids on development of in vitro-matured, in vitro-fertilized bovine oocytes in a chemically defined, protein- free culture medium. Biology of Reproduction 48: 1320-1325.

Lindner, G.M. \& Wright, R.W., Jr. 1983. Bovine embryo morphology and evaluation. Theriogenology 20: 407-416. Moore, K. \& Bondioli, K.R. 1993. Glycine and alanine supplementation of culture medium enhances development of in vitro matured and fertilized cattle embryos. Biology of Reproduction 48: 833-840.

Parrish, J.J., Susko-Parrish, J., Winer, M.A. \& First, N.L. 1988. Capacitation of bovine sperm by heparin. Biology of Reproduction 38: 1171-1180.

Pinyopummintr, T. \& Bavister, B.D. 1991. In vitro-matured/in vitro-fertilized bovine oocytes can develop into morulae/blastocysts in chemically defined, protein-free culture media. Biology of Reproduction 45: 736-742. Rao, L.V., Wikarczuk, M.L. \& Heyner, S. 1990. Functional roles of insulin and insulinlike growth factors in preimplantation mouse embryo development. In Vitro Cellular \& Developmental Biology 26: 1043-1048.

Rosenblum, I.Y., Mattson, B.A. \& Heyner, S. 1986. Stage-specific insulin binding in mouse preimplantation embryos. Developmental Biology 116: 261-263.

Rosenkrans, C.F. \& First, N.L. 1991. Culture of bovine zygotes to the blastocyst stage: effect of amino acids and vitamins. Theriogenology 35: 266. (Abstract).

Seidel, G.E., Jr, Glass, T. \& Olson, S.E. 1991a. Culture of 1 -cell bovine embryos to blastocysts in chemically defined media. Biology of Reproduction 44, Supplement 1: 155. (Abstract).

-, Nauta, W. \& Olson, S.E. 1991b. Effects of myoinositol, transferrin and insulin on culture of bovine embryos. Journal of Anirhal Science 69, Supplement 1: 403. (Abstract),

Takagi, Y., Mori, K., Tomizawa, M., Takahashi, T., Sugawara, S. \& Masaki, J. 1991. Development of bovine oocytes matured, fertilized and cultured in a serum-free, chemically defined medium. Theriogenology 35: 11971207.

Watson, A.J., Hogan, A., Hahnel, A., Wiemer, O.E. \& Schultz, G.A. 1992. Expression of growth factor ligand and receptor genes in the preimplantation bovine embryo. Molecular Reproduction and Development 31: 8795.

Zhang, X. \& Armstrong, D.T. 1990. Presence of amino acids and insulin in a chemically defined medium improves development of 8-cell rat embryos in vitro and subsequent implantation in vivo. Biology of Reproduction 42: 662-668. 
Bredbacka, K. \& Bredbacka, P. Bovine blastocyst production in defined medium

\title{
SELOSTUS
}

\section{Insuliinin vaikutus naudan blastokystien tuottamiseen in vitro kemiallisesti tunnetussa liuoksessa}

\author{
Kristiina Bredbacka ja Peter Bredbacka \\ Maatalouden tutkimuskeskus
}

Naudan alkion varhaiskehitystä tutkittiin viljelemällä alkioita kemiallisesti tunnetussa viljelyliuoksessa. Kokeessa käytetty liuos CR1-PVP on muunnos CR1aa-liuoksesta, jonka proteiinilähde, naudan seerumin albumiini, korvattiin $4 \mathrm{mg} / \mathrm{ml}$ polyvinyylipyrrolidonilla. Kokeessa käytetyt kolme insuliinipitoisuutta olivat 0,2 ja $200 \mathrm{nM}$. In vitro-tuotetut alkiot jaettiin hedelmöityksen jälkeen kolmeen viljelyryhmään: CR1-PVP, CR1- PVP + insuliini $(2 \mathrm{nM})$ ja CR1-PVP + insuliini (200 nM). Alkioita viljeltiin seitsemän päivää, ja neljäntenä päivänä lisättiin tuoretta viljelyliuosta ja glukoosia (lopullinen pitoisuus
5,56 mM). Viljelyn päättyessä alkiot arvioitiin kehitysvaiheen mukaan ja alkioiden solut laskettiin tumavärjäyksen jälkeen.

Proteiinittomassa viljelyliuoksessa saatiin blastokysteiksi kehittymään $8,7 \%$. Insuliinin lisäyksellä saatiin enemmän blastokystejä $(12,8 \%)$, mutta ei tilastollisesti merkitsevästi. Jakautumisprosentti, blastokystien osuus jakautuneista alkioista sekä morula/ blastokystivaiheen alkioiden tumalukumäärä $(\mathrm{P}=0,10)$ olivat korkeimmat ryhmässä, jossa insuliinipitoisuus oli $200 \mathrm{nM}$. 